\title{
Pulp revascularization: an alternative treatment to the apexification of immature teeth
}

\author{
Revascularização pulpar: tratamento alternativo à apicificação de dentes jovens com rizogênese incompleta
}

Maria Tereza Pedrosa ALBUQUERQUE ${ }^{1}$

Juliana Yuri NAGATA²

Adriana de Jesus SOARES²

Alexandre Augusto ZAIA²

\begin{abstract}
Pulp revascularization can be considered as a current alternative treatment to apexification, recommended for immature teeth cases, requiring endodontic treatment. Apexification involves long-term periodic exchanges of a calcium hydroxide paste into the root canal to induce the formation of a calcified barrier. Despite being the most classically therapy employed for these cases, the permanence of calcium hydroxide for long periods of time and also the successive changes may lead to a weakening of the root due to its hygroscopic properties and the proteolytic activities of calcium hydroxide, increasing the risk of fractures and contamination of the pulp space. Thus, a constant search for new treatment alternatives that provide the end of root development have been done to avoid the risk of future root fractures. So, revascularization has emerged as a new treatment option for cases of undeveloped teeth, that provides not only apical closure, as apexification, but also increase the dentin walls thickness. In the literature, there is an assortment of treatment protocols employing pulp revascularization procedure in attempt to attain the best way to achieve success. Assuming the diversity of protocols for revascularization treatment, it is important to go deep in the literature to collect, describe and discuss these protocols guiding new researches in this field and also conducting the clinicians. Therefore, this review aims to assess the literature on the different revascularization protocols.
\end{abstract}

Indexing terms: Dental pulp. Endodontics. Regeneration.

\section{RESUMO}

A revascularização pulpar pode ser considerada atualmente como um tratamento alternativo à apicificação e é indicado para dentes com rizogênese incompleta e necessidade de tratamento endodôntico. A apicificação envolve a realização de trocas periódicas em longo prazo de uma pasta de hidróxido de cálcio com o objetivo de formar uma barreira calcificada. Apesar de ser a terapia mais empregada, a permanência desta medicação por longos períodos e as trocas sucessivas, podem levar à fragilização da raiz devido às propriedades higroscópicas e proteolíticas do hidróxido de cálcio, aumentando o risco de fraturas e contaminação do espaço pulpar. Desta forma, tem-se buscado novas alternativas de tratamento que possibilitem o fechamento do forame apical dos dentes imaturos sem que ocorra a fragilização dos mesmos. A revascularização pulpar tem surgido como uma nova opção de tratamento para estimular o término do desenvolvimento radicular e não apenas o fechamento apical. Há na literatura uma variedade de protocolos utilizando esta técnica, buscando sempre alcançar o sucesso no tratamento. Diante dessa variedade, é de grande importância a realização de uma revisão de literatura sobre revascularização pulpar visando reunir, descrever e discutir os diferentes protocolos, para que possam direcionar novas pesquisas e ser empregada de forma adequada pelo clínico. O objetivo desse trabalho é revisar na literatura os diferentes protocolos de revascularização pulpar.

Termos de indexação: Polpa dentária. Endodontia. Regeneração.

\section{INTRODUCTION}

Research involving revascularization procedures has been developed since the 1950's and 1960's, however then the focus was somewhat different, aiming to revascularize the ischemic pulp tissue following injury involving immature teeth. It was observed that replanted or transplanted teeth could recover their revascularized tissue in spite of the injury ${ }^{1-4}$. In 1961, Östby ${ }^{5}$ observed in his study the importance of the blood clot in the periapical healing of teeth with empty root canals.
In the late 70's and early 80's, in vivo studies on dogs evaluated the capacity of ischemic pulp tissue to revascularize after having been replanted due to avulsion. They observed that some teeth developed revascularization of pulp tissue and in others, tooth resorption was initiated without revascularization ${ }^{6-7}$. In addition, these authors found that a shorter extra-alveolar time could improve the prognosis of success in avulsed teeth. One year later, Kling et al. ${ }^{8}$ correlated some factors in the prognosis of replanted teeth, i.e. frequency of pulp revascularization of replanted incisors, apical foramen diameter, extra-alveolar time, storage

\footnotetext{
${ }^{1}$ Universidade Estadual Paulista Júlio de Mesquita, Faculdade de Odontologia, Programa de Pós-Graduação em Odontologia, Departamento de Endodontia. Rua Engenheiro Francisco José Longo, 777, 12245-000, São José dos Campos, SP, Brasil. Correspondência para / Correspondence to: MTP ALBUQUERQUE. E-mail: <terezapedrosa@hotmail.com>.

2 Universidade Estadual de Campinas, Faculdade de Odontologia, Programa de Pós-Graduação em Clínica Odontológica, Departamento de Endodontia. Piracicaba, SP, Brasil.
} 
medium and post-operatory prescription of antimicrobials. It was demonstrated that immature teeth maintained in favorable extra-alveolar conditions for less than 45 minutes could provide a greater possibility of pulp revascularization.

In the 90's, more precise researchers of monkeys evaluated the action of systemic antibiotic administration on the pulp revascularization of ischemic pulp tissue due to tooth avulsion?. Results demonstrated that systemic antibiotics could not prevent pulp tissue contamination.

In general, most of the studies in the past have stated that pulp tissue vitality could be reestablished after replantation of immature teeth through the hypothesis of revascularization. However, Ostby ${ }^{5}$ already reported that loss of pulp tissue vitality, leaving an empty root canal space, could be repaired with ingrowth of periapical tissue through apical foramen, provided that a sterilized environment can be maintained. Despite the relevance of this reflection, little relevance was attributed to it at the time.

From 2000, revascularization began to be reported as an alternative to apexification. Researchers focused their attention on the possibility of achieving root-end development (i.e. apical closure, increasing width and length of root dentin) in necrotic, immature teeth after a careful endodontic treament ${ }^{10}$. Iwaya et al. ${ }^{11}$, reported a clinical case of an immature tooth diagnosed with pulp necrosis that was treated with root canal decontamination using irrigant solution and triple antibiotic paste, followed by definitive restoration. Radiographically, the thickness of the dentinal wall of the tooth had increased, apical closure and repair of periapical lesion after monitoring for 5 months. Later, several case reports ${ }^{12-17}$ used different chemical irrigants and intracanal medications, most of which irrigated the root canal with sodium hypochlorite, whether or not combined with intracanal dressing with antibiotics.

Besides the case reports, clinical research 1,18-19 and in vivo animal studies $20-23$, also investigated pulp revascularization results. Firstly, these protocols promote root canal disinfection, followed by blood clot induction from the periapical region and ultimately coronary sealing ${ }^{1}$. Thus, it creates a favorable environment for the proliferation of new tissue. All these recent studies were designed in accordance with previous findings using replanted or transplanted, immature teeth that healed through the replacement of necrotic pulp tissue via revascularization ${ }^{9,24}$.

In addition, recently, it has been investigated whether pulp metaplasia or pulp regeneration may occur after pulp revascularization ${ }^{25}$. Pulp metaplasia refers to the repair of root canal space through the formation of periodontal ligamentlike cells and osteoblast-like cells. On the other hand, pulp regeneration occurs when new pulp tissue develops with the same characteristics as the damaged tissue.

Based on the importance attributed to conservative endodontic treatments and considering the possibility of obtaining promising outcomes using pulp revascularization treatment, this study aimed to review the literature on pulp revascularization, highlighting the main aspects of the protocols used that could have a positive influence with the critical analysis of the conduct of immature teeth, mainly concerning the recommendation of revascularization as an alternative to apexification.

\section{Pulp revascularization/revitalization and regeneration concepts}

Pulp regeneration may be defined as the replacement of damaged tissue by cells identical to the lost tissue, leading to the complete reestablishment of biological function ${ }^{26}$. Unlike regeneration, tissue healing promotes the replacement of damaged tissue with a different tissue consisting of a fibrosis or scar. Thus, tissue lesion healing may not lead to tissue regeneration, since only an embryo in the first few months of gestation (until week 24) is able to completely regenerate when damaged, and any tissue lesion after birth will always be associated with a scar, at the very least ${ }^{27}$. Therefore, the healing of irreversible pulpitis, pulp necrosis and apical periodontitis after endodontic treatment is not related to complete regeneration of damaged tissue ${ }^{26}$. Pulp tissue regeneration in vitro, developed using stem cells, may, in the future, become a reality since the new tissue would be developed in a favorable environment using undifferentiated cells presenting high potential for differentiation, stimulated by specific growth factors ${ }^{28}$. Complete regeneration of infected/inflamed periapical tissue in immature, necrotic teeth is unlikely to happen, however removal of the aggression factor (infection) may create a favorable environment for tissue repair. In this context, the outcome of pulp revascularization/revitalization may be explained through the same mechanism of tissue repair.

Revascularization may be defined as the invagination of undifferentiated periodontal cells from the apical region in immature teeth ${ }^{29-30}$. Tissue ingrowth is directed towards the root canal space after passive decontamination that removes, partially or totally, pulp tissue and/or its necrotic remnants. Some protocols used to fill root canal space with blood clots from periapical tissues, which can contribute to transporting periodontal stem cells inside the root canal space. Periodontal/ periapical cells have been related to the desirable outcomes of pulp revascularization (root-end development 
and apical closure). Besides the so-called revascularization terminology, pulp revitalization has also been used to define the formation of vital tissue inside the root canal. However, this definition could promote a conceptual conflict since pulp tissue possesses specific histological features that the invaginated tissue, originating from periapical tissue, may not reproduce. In addition, revitalization of tissue could create the idea of residual necrotic or inflamed pulp tissue undergoing regeneration (development of an identical pulp tissue filling the root canal space).

\section{How does revascularization happen?}

There are a number of theories that explain the revascularization mechanism. The periapical region of immature teeth presents multipotent periodontal cells with great potential for differentiating into new fibroblasts and cementoblasts $^{31}$. So, it has been suggested that differentiated cementoblasts and fibroblasts are responsible for increasing dentinal walls and apical closure1. Another hypothesis suggests that residual multipotent stem cells from pulp tissue may be abundant in young, immature teeth, adhering to dentinal walls to generate odontoblast-like cells for rootend development ${ }^{31}$. A third possibility involves the ingrowth of stem cells from apical papilla that could proliferate inside root canals through the blood induction of periapical tissues, since these cells have high proliferative capacity, probably being transported inside root canals in association with bleeding induced from the periapical tissue ${ }^{32}$.

In addition to the abovementioned hypothesis, various growth factors incorporated in the blood clot and/ or dentin may play an important role in the cell proliferation inside the root canal space ${ }^{33-34}$. Finally, the root anatomy of immature teeth (e.g. presenting open apex, wide root canal and thin radicular dentin walls) may favor the communication of canal space and periodontal tissue to achieve apical healing with periodontal tissue. With regard to the apical opening, revascularization seems to be more predictable when the apical diameter is greater than 1 $\mathrm{mm}$ and is unlikely to occur in apical openings narrower than $0.3 \mathrm{~mm}^{25}$. This type of repair was previously described in classic studies with dogs that induced the formation of blood clots in immature teeth filled beyond the apex foramen, resulting in the ingrowth of periodontal tissue repair in the region ${ }^{5}$.

\section{Root canal decontamination}

The first step in the endodontic treatment of infected root canals involves disinfection through the use of chemical substances and mechanical instrumentation ${ }^{35}$.
However, in immature teeth, the mechanical removal of microorganisms is not recommended due to the fragility of the thin root walls, requiring a decontamination restricted to the use of irrigant solutions and intracanal medication ${ }^{36-37}$.

\section{Irrigant solutions}

The chemical substances used most frequently worldwide are sodium hypochlorite $(\mathrm{NaOCl})$ and chlorhexidine $(\mathrm{CHX})^{37}$. $\mathrm{NaOCl}$ possesses antimicrobial properties against most endodontic pathogen $\mathrm{s}^{38}$, being used in concentrations ranging from $0.5 \%$ to $6 \%$. From the standpoint of pulp revascularization, more concentrated solutions are preferred, mainly $2.5 \%$ and $6 \%$, to obtain clinical success ${ }^{10}$. As for chlorhexidine, case reports have used concentrations of $2 \%{ }^{15,39}$ and $0.12 \%^{40}$. Despite satisfactory antimicrobial properties, these substances are not biocompatible, limiting the survival of dental pulp stem cells and adherence to dentinal walls $s^{41}$. In addition to irrigant solutions, chelating agents such as EDTA, citric acid and MTAD may also be used to remove the smear layer. MTAD was recently introduced by Torabinejad et al. ${ }^{42}$, being composed of $3 \%$ thiosulfate, $4.25 \%$ citric acid and $0.5 \%$ polysorbate. Meanwhile, EDTA is the most commonly used chelating agent, also capable of inducing the release of various growth factors incorporated in the human dentin matrix ${ }^{43}$. Although appearing to be a substance with some promise, it is not known if EDTA could damage the stem cell proliferation process during revascularization ${ }^{44}$.

Taking into consideration the importance of stem cells for both revascularization and regeneration, studies have evaluated cytotoxicity and interference of chemical substances in the adhesion of stem cells ${ }^{41}$. $\mathrm{NaOCl}, \mathrm{CHX}$, Aquatine Endodontic Cleanser (AquatineEC), Morinda

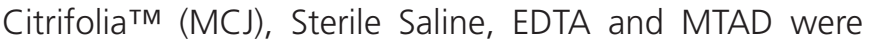
evaluated both individually and in combination. It was shown that $\mathrm{NaOCl}$ and $\mathrm{CHX}$ presented cytotoxic effects, leading to a decrease in dental pulp stem cell adherence to the dentinal walls and, moreover, the presence of a smear layer did not have any influence on this adherence. AquatineECTM is a new irrigant solution used to irrigate, clean and debride the root canal system ${ }^{41}$. Hypochlorous acid $(\mathrm{HOCl})$ is the active component, with biocompatibility and antimicrobial features against most endodontic pathogens ${ }^{44-45}$. Compared to $\mathrm{NaOCl}$ and $\mathrm{CHX}$, AquatineECTM was less toxic to dental pulp stem cells and allowed cell adherence to root walls ${ }^{41}$. However, further studies should be performed to better understand its properties and possible use in regenerative endodontics. 


\section{Intracanal medications}

Pulp revascularization is more favorable in a bacteria-free environment ${ }^{46}$, which requires a clean and disinfected root canal system prior to cell colonization. Root canal system infection is composed of multiple species of bacteria, unlikely to allow just one antibiotic to combat these microorganisms in order to create a sterile environment ${ }^{20}$. Therefore, Hoshino et al. ${ }^{47}$, evaluated single and combined antibiotics against endodontic bacteria. They observed that the association of three antibiotics (Metronidazole, Ciprofloxacin and Minocycline) eliminated bacteria colonizing the dentin surface. In addition, this paste killed bacteria inside deep layers of dentin ${ }^{48}$.

Based on these initial studies, research and case reports related to pulp revascularization started to use antibiotic paste as the gold-standard for intracanal medication, in order to control infection inside root canals, and at the same time allow ingrowth of new tissue to continue root development. Antibiotic paste is composed of $400 \mathrm{mg}$ Metronidazole, $250 \mathrm{mg}$ Ciprofloxacin and $50 \mathrm{mg}$ Minocycline, manipulated in propylene glycol vehicle to achieve a creamy consistency. The paste may be inserted through the use of a Lentulo spiral drill, syringe or manual files (Figure 1). Despite promising results, antibiotic paste may manifest some side effects such as crown discoloration due to the presence of minocycline ${ }^{16}$, a semi-synthetic tetracycline effective against Gram-positive and Gram-negative bacteria $^{20}$. In an attempt to minimize these undesirable effects, some authors have suggested decreasing the time of the antibacterial dressing to prevent discoloration ${ }^{16}$, given that antimicrobial action may last between 24 and 48 hours ${ }^{47-48}$. However, it is not known if a shorter period of time in contact with minocycline could prevent discoloration, since after 24 hours, crown discoloration is already visible ${ }^{16}$.
The development of microbial resistance represents another relevant factor related to triple antibiotic paste, however to date there is no consensus over this assertion. It is merely speculated that dressing root canals with this paste could decrease the probability of development of resistant bacteria ${ }^{49}$.

Taking into consideration the limitations of this paste, studies have investigated alternatives with antimicrobial properties to disinfect the root canal system $^{50}$. Calcium hydroxide is traditionally used as an intracanal medication in endodontic routines and in cases of apexification ${ }^{51}$, due to antimicrobial properties that limit microbial proliferation ${ }^{52}$. Recently, calcium hydroxide has also been tested with pulp revascularization, showing clinical and radiographic success ${ }^{17,53}$. Studies have demonstrated that dressing root canals with calcium hydroxide can solubilize bioactive molecules, including growth factors of human dentin matrix that would likely stimulate mesenchymal pulp cells to differentiate into odontoblast-like cells $s^{43}$, also preventing damage to Hertwig's epithelial root sheath cells ${ }^{54}$. On the other hand, one study emphasized that calcium hydroxide could damage the epithelial cell rests of Malassez, supposedly an important structure for cell proliferation ${ }^{12}$. Comparing the abovementioned intracanal medications, Bose et al. ${ }^{55}$ showed that both calcium hydroxide and triple antibiotic paste were effective in assisting pulp-dentin complex. These results occurred when calcium hydroxide insertion was limited to the cervical third of the root canal.

Pulp revascularization is generally performed over two clinical sessions. In the first session, root canals are cleaned through copious irrigation with chemical substances, followed by dressing with intracanal medication for three weeks. After this period, a blood clot is induced (Figure 2) and sealed with Mineral Trioxide Aggregate (MTA) and composite resin.

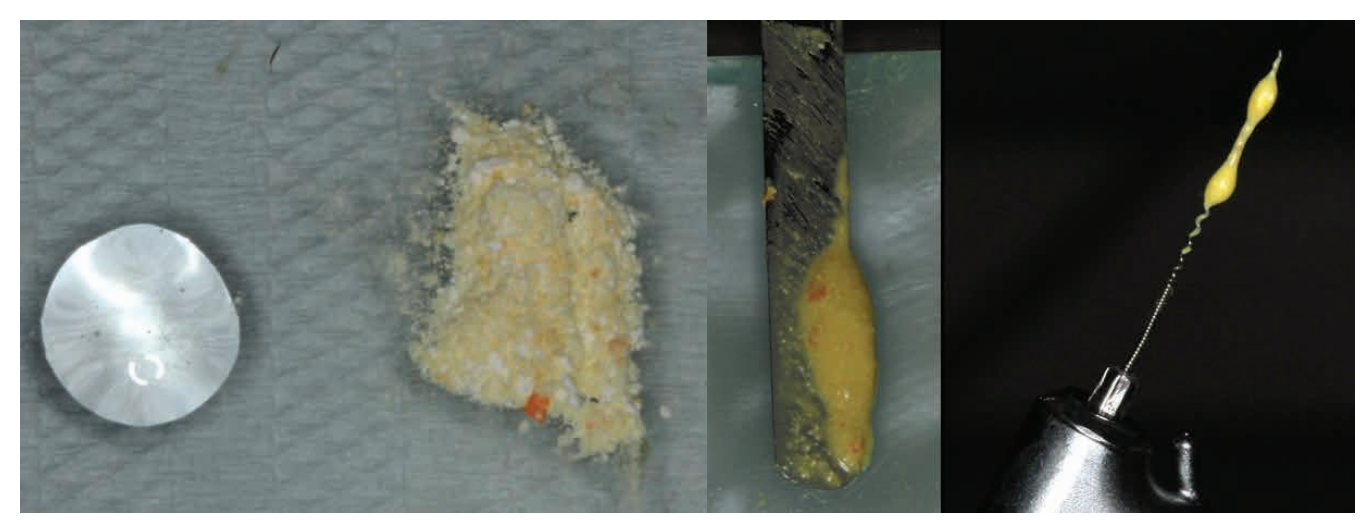

Figure 1. Images showing triple antibiotic paste consistence and insertion. 


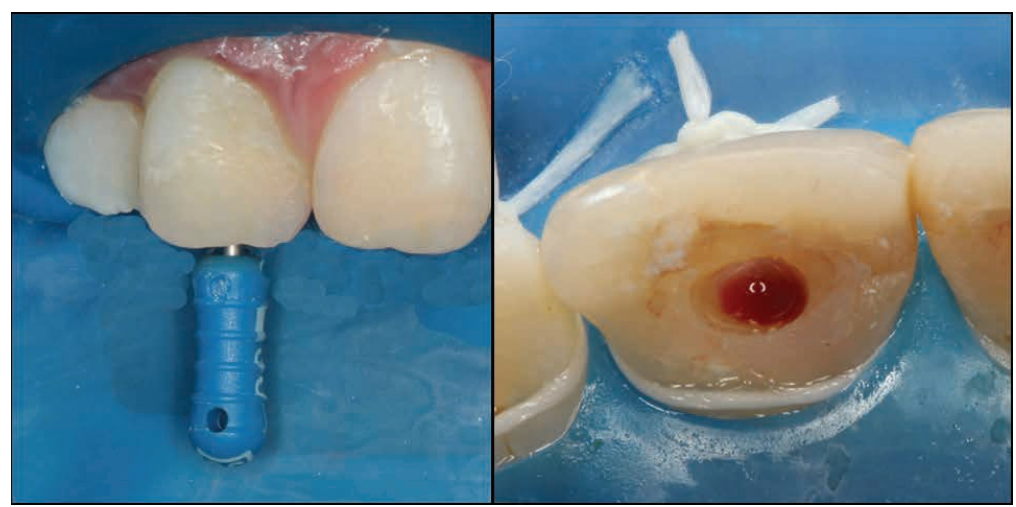

Figure 2. Blood clot stimulation with a manual endodontic file.

Although most studies have tended to perform the therapy in two separate sessions, Shin et al. ${ }^{39}$ performed pulp revascularization in a single visit through root canal decontamination with $6 \%$ sodium hypochlorite, sterile saline solution and $2 \%$ chlorhexidine, without mechanical instrumentation, followed by MTA/composite resin sealing. The authors demonstrated root-end development and increased width of the dentin walls. A variety of case reports and studies have been published, however, future literature still requires the investigation of disinfection protocols to prevent microbial resistance, and also biomaterials capable of causing the induction of angiogenesis to allow cell nutrition to finally achieve tissue regeneration ${ }^{15}$.

\section{Protocols}

Revascularization represents a recent and promising topic that has been in evidence due to the preservation of biological principles and the possibility of minimizing the treatment period of immature teeth. Therefore, a great variety of treatment protocols using this therapy exist, in order to achieve the most appropriate path to success.

Table 1 illustrates the diversity of protocols available in the literature. Disinfection substances, the type of intracanal medication (when used), period of time dressing the intracanal medication and coronal sealing were described.

Table 1. Pulp revascularization protocols according to literature.

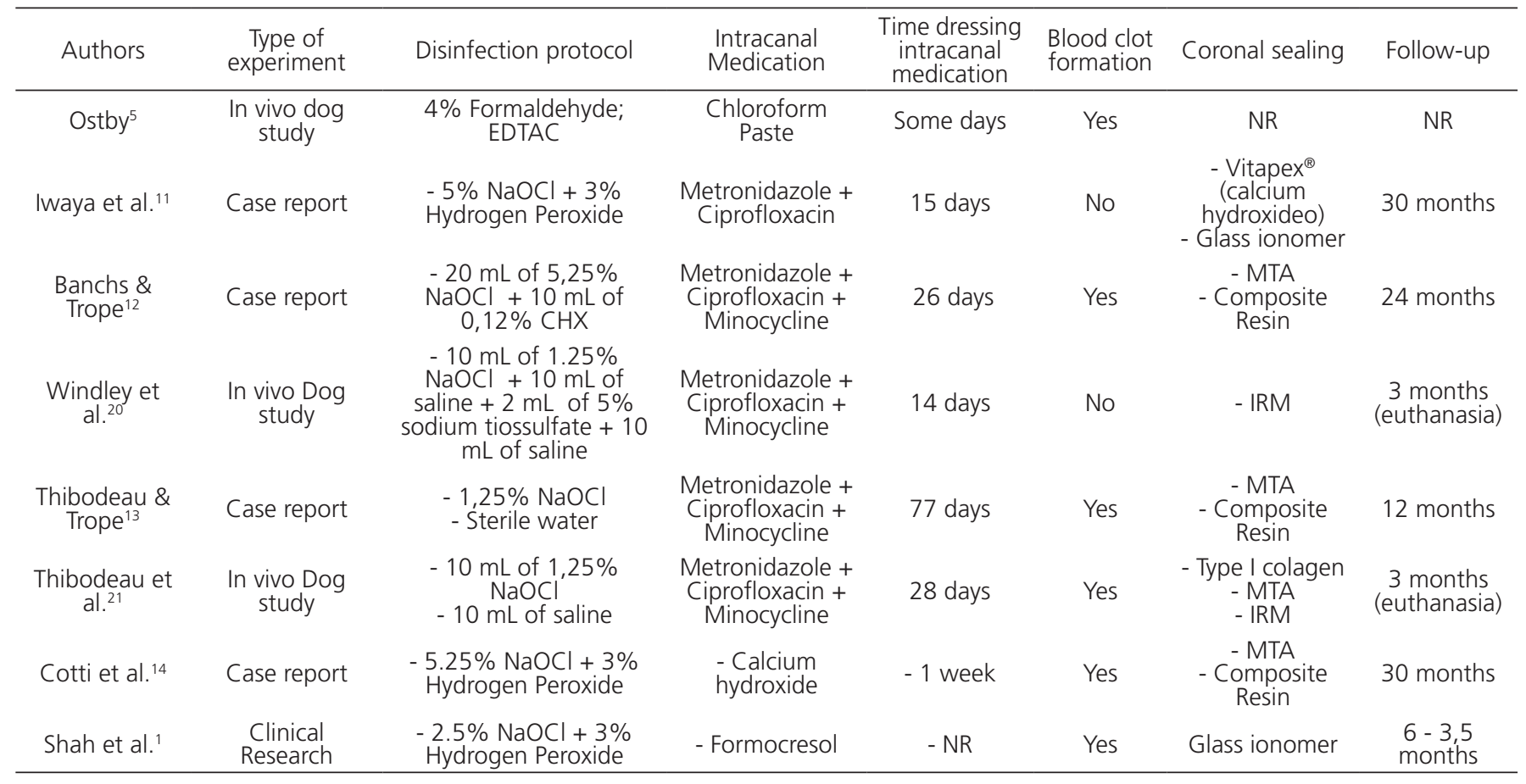




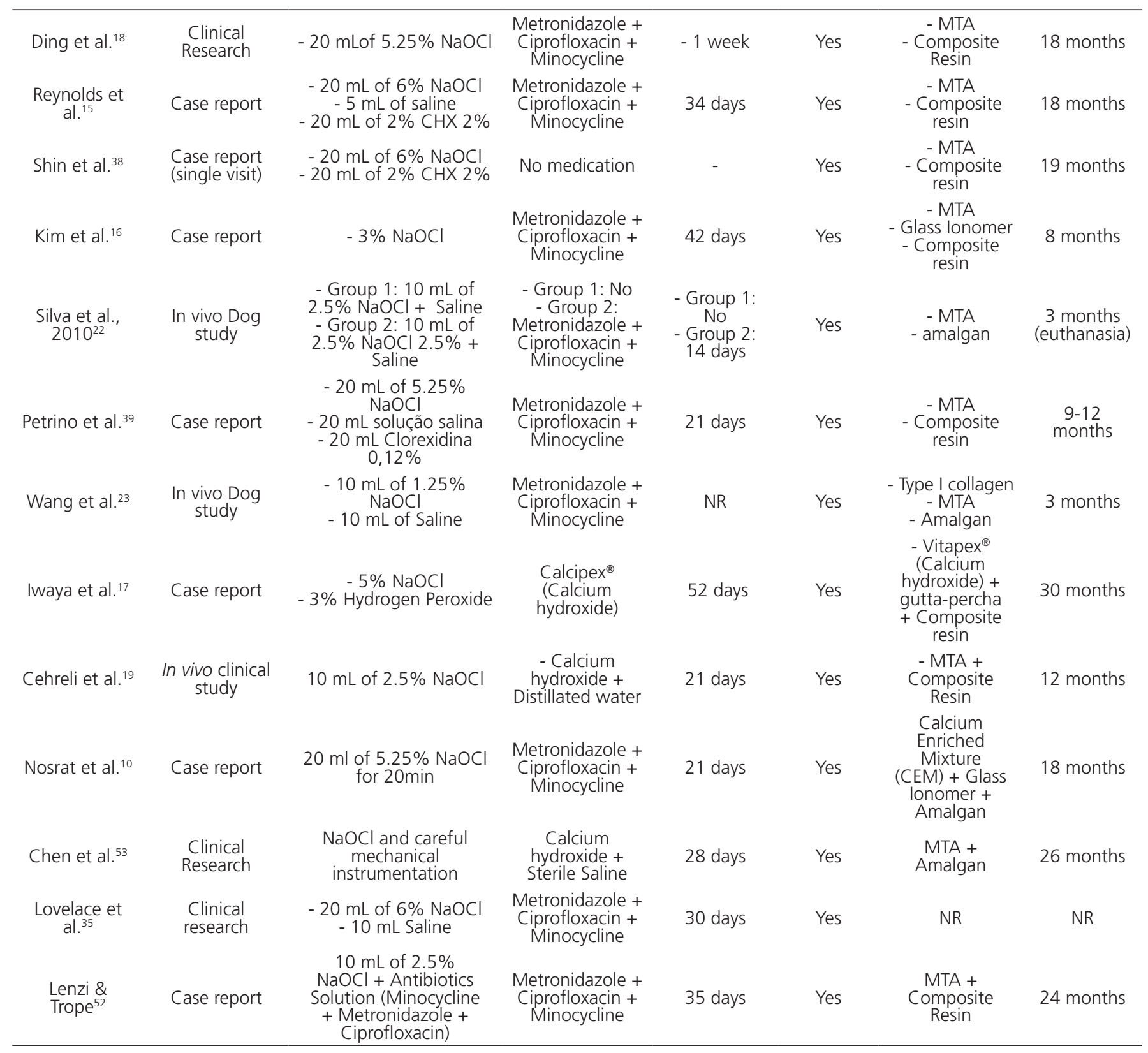

*NR: Not reported

\section{Follow-up}

The follow-up of clinical cases of revascularization is mandatory to verify clinical success. A period of approximately 6 months is required, after the treatment, to evaluate success and to identify treatment progress $5^{55-56}$. The literature reports a follow-up period ranging from months to years with different root development outcomes. Chueh et al. ${ }^{52}$ showed that complete root formation of necrotic, immature teeth associated with periapical lesion was achieved only after a follow-up period of between 10 and 13 months.

According to Chen et al. ${ }^{57}$ immature teeth diagnosed with pulp necrosis and apical periodontitis may present four types of revascularization outcome: Type I, increased dentin wall width and root-end development; Type II, insignificant continued root development associated with apical closure; Type III, root-end development without apical closure; Type IV, calcification (obliteration) of root canal; Type $\mathrm{V}$, mineralized tissue barrier between MTA cervical plug and radicular apex.

\section{CONCLUSION}

Pulp revascularization represents a recent and promising therapy for immature teeth, recommended as an alternative to apexification in cases of endodontic 
treatment of irreversible pulpitis and pulp necrosis, whether or not associated with periapical lesion. It is a technically simple treatment with advantageous outcomes because, unlike apexification, it promotes thickness of the dentin wall width and apical closure, avoiding weakening of the tooth. However, considering that it has only recently begun to be applied, little is known about long-term side effects. Further clinical studies with long-term follow-up may contribute to an understanding of the composition and mechanical properties of the mineralization developed in the inner dentinal walls. In addition, the need for

\section{REFERENCES}

1. Shah N, Logani A, Bhaskar U, Aggarwal V. Efficacy of revascularization to induce apexification/apexogensis in infected, nonvital, immature teeth: a pilot clinical study. J Endod. 2008;34(8):919-25. doi: 10.1016/j.joen.2008.05.001

2. Hale MS. Autogenous transplants. J Am Dent Assoc. 1954;49:193.

3. Myers HI, Flanagan VD. A comparison of the results obtained from transplantation and replantation experiments using Syrian hamster teeth. Anat Rec 1958;130(3):497-513. doi: 10.1002/ ar.1091300303

4. Pafford EM. Homogenous transplants of preserved frozen teeth. Oral Surg Oral Med Oral Pathol. 1956;9(1):55-70.

5. Ostby BN. The role of the blood clot in endodontic therapy: an experimental histologic study. Acta Odontol Scand. 1961;19:324-53.

6. Johnson DS, Burich RL. Revascularization of reimplanted teeth in dogs. J Dent Res. 1979;58(2):671. doi: $10.1177 / 00220345790580022501$

7. Sheppard PR, Burich RL. Effects of extra-oral exposure and multiple avulsions on revascularization of reimplanted teeth in dogs. J Dent Res. 1980;59(2):140. doi: 10.1177/00220345800590021101

8. Kling $M$, Cvek $M$, Mejare I. Rate and predictability of pulp revascularization in therapeutically reimplanted permanent incisors. Endod Dent Traumatol. 1986;2(3):83-9. doi: 10.1111/ j.1600-9657.1986.tb00132.x

9. Cvek M, Cleaton-Jones P, Austin J, Lownie J, Kling M, Fatti P. Pulp revascularization in reimplanted immature monkey incisors-predictability and the effect of antibiotic systemic prophylaxis. Endod Dent Traumatol. 1990;6(4):157-69.

10. Nosrat A, Seifi A, Asgary S. Regenerative endodontic treatment (revascularization) for necrotic immature permanent molars: a review and report of two cases with a new biomaterial. J Endod. 2011;37(4):562-7. doi: 10.1016/j.joen.2011.01.011

11. Iwaya SI, Ikawa M, Kubota M. Revascularization of an immature permanent tooth with apical periodontitis and sinus tract. endodontic retreatment and intracanal post rehabilitation in revascularized teeth must be planned in order to extend immature tooth longevity and improve future prognosis.

\section{Collaborators}

MTP ALBUQUERQUE and JY NAGATA were responsible for the review of the literature, selection of papers, scientific writing and discussion of each topic. AJ SOARES and AA ZAIA were responsible for review, suggestions and the scientific writing.

Dent Traumatol. 2001;17(4):185-7. doi: 10.1034/j.16009657.2001.017004185.x

12. Banchs F, Trope M. Revascularization of immature permanent teeth with apical periodontitis: new treatment protocol? J Endod. 2004;30(4):196-200. doi:10.1097/00004770-20040400000003

13. Thibodeau B, Trope M. Pulp revascularization of a necrotic infected immature permanent tooth: case report and review of the literature. Pediatr Dent. 2007;29(1):47-50.

14. Cotti E, Mereu M, Lusso D. Regenerative treatment of an immature, traumatized tooth with apical periodontitis: report of a case. J Endod. 2008;34(5):611-6. doi: 10.1016/j. joen.2008.02.029

15. Reynolds K, Johnson JD, Cohenca N. Pulp revascularization of necrotic bilateral bicuspids using a modified novel technique to eliminate potential coronal discolouration: a case report. Int Endod J. 2009;42(1):84-92. doi: 10.1111/j.13652591.2008.01467.x

16. Kim JH, Kim Y, Shin SJ, Park JW, Jung Y. Tooth discoloration of immature permanent incisor associated with triple antibiotic therapy: a case report. J Endod. 2010;36(6):1086-91. doi: 10.1016/j.joen.2010.03.031

17. Iwaya S, Ikawa M, Kubota M. Revascularization of an immature permanent tooth with periradicular abscess after luxation. Dent Traumatol. 2011;27(1):55-8. doi: 10.1111/j.16009657.2010.00963.x

18. Ding RY, Cheung GS, Chen J, Yin XZ, Wang QQ, Zhang CF. Pulp revascularization of immature teeth with apical periodontitis: a clinical study. J Endod. 2009;35(5):745-9. doi: 10.1016/j. joen.2009.02.009

19. Cehreli ZC, Isbitiren B, Sara S, Erbas G. Regenerative endodontic treatment (Revascularization) of immature necrotic molars medicated with calcium hydroxide: a case series. J Endod. 2011;37(9):1327-30. doi: 10.1016/j.joen.2011.05.033

20. Windley W, Teixeira F, Levin L, Sigurdsson A, Trope M. Disinfection of immature teeth with a triple antibiotic paste. J Endod. 2005;31(6):439-43. doi: 10.1097/01. don.0000148143.80283.ea 
21. Thibodeau B, Teixeira F, Yamauchi M, Caplan DJ, Trope M. Pulp revascularization of immature dog teeth with apical periodontitis. J Endod. 2007;33(6):680-9. doi: doi:10.1016/j. joen.2007.03.001

22. Silva LAB, Nelson-Filho P, Silva RAB, Flores DSH, Heilborn C, Johnson JD, et al. Revascularization and periapical repair after endodontic treatment using apical negative pressure irrigation versus conventional irrigation plus triantibioticintracanal dressing in dogs' teeth with apical periodontitis. Oral Surg Oral Med Oral Pathol Oral Radiol Endod. 2010;109(5):779-87. doi: 10.1016/j. tripleo.2009.12.046

23. Wang $X$, Thibodeau B, Trope M, Lin LM, Huang GT. Histologic characterization of regenerated tissues in canal space after the revitalization/revascularization procedure of immature dog teeth with apical periodontitis. J Endod. 2010;36(1):56-63. doi: 10.1016/j.joen.2009.09.039

24. Skoglund A, Tronstad L, Wallenius K. A microangiographic study of vascular changes in replanted and autotransplanted teeth of young dogs. Oral Surg Oral Med Oral Pathol. 1978;45(1):17-28. doi:10.1016/0030-4220(78)90217-7

25. Andreasen JO. Pulp and periodontal tissue repair - regeneration or tissue metaplasia after dental trauma: a review. Dent Traumatol. 2012; 28(1):19-24. doi: 10.1111/j.1600-9657.2011.01058.x

26. Lin LM, Rosenberg PA. Repair and regeneration in endodontics. Int Endod J. 2011;44(10):8891-906. doi: 10.1111/j.13652591.2011.01915.x

27. Colwell AS, Longaker MT, Lorenz HP. Fetal wound healing. Frontiers Bioscience. 2003;8:S1240-8.

28. Shi S, Gronthos S. Perivascular niche of postnatal mesenchymal stem cells in human bone marrow and dental pulp. J Bone Miner Res. 2003;18(4):696-704. doi: 10.1359/ jbmr.2003.18.4.696

29. Zhang W, Yelick PC. Vital pulp therapy-current progress of dental pulp regeneration and revascularization. Int J Dent. 2010;28:19. doi: 10.1155/2010/856087

30. Garcia-Godoy F, Murray PE. Recommendations for using regenerative endodontic procedures in permanent immature traumatized teeth. Dent Traumatol. 2012;28(12):33-41. doi: 10.1111/j.1600-9657.2011.01044.x

31. Saad AY. Calcium hydroxide and apexogenesis. Oral Surg Oral Med Oral Pathol. 1988;66(4):499-501.

32. Gronthos S, Mankani M, Brahim J, Robey PG, Shi S. Postnatal human dental pulp stem cells (DPSCs) in vitro and in vivo. Proc Natl Acad Sci USA. 2000;97(25):1325-30.

33. Lieberman J, Trowbridge H. Apical closure of nonvital permanent incisor teeth where no treatment was performed: case report. J Endod. 1983;9(6):257-60. doi: 10.1016/S00992399(86)80025-5

34. Wang Q, Lin XJ, Lin ZY, Liu GX, Shan XL. Expression of vascular endothelial growth factor in dental pulp of immature and mature permanent teeth in human. Shanghai Kou Qiang Yi Zue. 2007;16(3):285-9.

35. Bystrom A, Sundqvist G. Bacteriologic evaluation of the efficacy of mechanical root canal instrumentation in endodontic therapy.
Scand J Dent Res. 1981;89(4):321-8. doi: 10.1111/j.16000722.1981.tb01689.x

36. Lovelace TW, Henry MA, Hargreaves KM, Diogenes A. Evaluation of the delivery of mesenchymal stem cells into the root canal space of necrotic immature teeth after clinical regenerative endodontic procedure. J Endod. 2011;37(2):133-8. doi: 10.1016/j.joen.2010.10.009

37. Clarkson RM, Moule AJ. Sodium hypochlorite and its use as an endodontic irrigant. Aust Dent J. 1998;43(4):250-6. doi: 10.1111/j.1834-7819.1998.tb00173.x

38. Bystrom A, Sundqvist G. The antibacterial action of sodium hypochlorite and EDTA in 60 cases of endodontic therapy. Int Endod J. 1985;18(1):35-40. doi: 10.1111/j.1365-2591.1985.tb00416.x

39. Shin SY, Albert JS, Mortman RE. One step pulp revascularization treatment of an immature permanent tooth with chronic apical abscess: a case report. Int Endod J. 2009;42(12):1118-26. doi: 10.1111/j.1365-2591.2009.01633.x

40. Petrino JA, Boda KK, Shambarger S, Bowles WR, McClanahan SB. Challenges in regenerative endodontics: a case series. J Endod. 2010;36(3):536-41. doi: 10.1016/j.joen.2009.10.006

41. Ring KC, Murray PE, Namerow KN, Kuttler S, Garcia-Godoy F. The comparison of the effect of endodontic irrigation on cell adherence to root canal dentin. J Endod. 2008;34(12):1474-9. doi: 10.1016/j.joen.2008.09.001

42. Torabinejad M, Khademi AA, Babagoli J, Cho Y, Johnson WB, Bozhilov $\mathrm{K}$, et al. A new solution for the removal of the smear layer. J Endod. 2003;29(3):170-5. doi:10.1097/00004770200303000-00002

43. Graham L, Cooper PR, Cassidy N, Nor JE, Sloan AJ, Smith AJ. The effect of calcium hydroxide on solubilisation of bio-active dentine matrix components. Biomaterials. 2006;27(14):286573. doi:10.1016/j.biomaterials.2005.12.020

44. Hargreaves KM, Geisler T, Henry M, Wang Y. Regeneration potential of the young permanent tooth: what does the future hold? Pediatr Dent. 2008;30(3):253-60.

45. Fukuzaki S. Mechanisms of actions of sodium hypochlorite in cleaning and disinfection processes. Biocontrol Sci. 2006;11(4):147-57.

46. Turkistani J, Hanno A. Recent trends in the management of dento alveolar traumatic injuries to primary and young permanent teeth. Dent Traumatol. 2011;27(1):46-54. doi: 10.1111/j.16009657.2010.00950.x

47. Hoshino E, Kurihara-Ando N, Sato I, Uematsu H, Sato M, Kota $\mathrm{K}$, et al. In-vitro antibacterial susceptibility of bacteria taken from infected root dentine to a mixture of ciprofloxacin, metronidazole and minocycline. Int Endod J. 1996;29(2):125-30.

48. Sato I, Ando-Kurihara N, Kota K, Iwaku M, Hoshino E. Sterilization of infected root-canal dentine by topical application of a mixture of ciprofloxacin, metronidazole and minocycline in situ. Int Endod J. 1996;29(2):118-24.

49. Mohammadi Z, Abbott PV. On the local applications of antibiotics and antibiotic-based agents in endodontics and dental traumatology. Int Endod J. 2009;42(7):555-67. doi: 10.1111/j.1365-2591.2009.01564.x 
50. Wigler R, Kaufman AY, Lin S, Steinbock N, Hazan-Molina H, Torneck CD. Revascularization: a treatment for permanent teeth with necrotic pulp and incomplete root development. J Endod. 2013;39(3):319-26. doi: 10.1016/j.joen.2012.11.014

51. Cvek M. Treatment of non-vital permanent incisors with calcium hydroxide I. Follow-up of periapical repair and apical closure of immature roots. Odontol Revy. 1972;23(1):27-44.

52. Chueh LH, Huang GTJ. Immature teeth with periradicular periodontitis or abscess undergoing apexogenesis: a paradigm shift. J Endod. 2006;32(12):1205-13. doi:10.1016/j. joen.2006.07.010

53. Bose R, Nummikoski P, Hargreaves K. A retrospective evaluation of radiographic outcomes in immature teeth with necrotic root canal systems treated with regenerative endodontic procedures. J Endod. 2009;35(10):1343-9. doi: 10.1016/j.joen.2009.06.021

54. Soares Ade J, Lins FF, Nagata JY, Gomes BP, Zaia AA, Ferraz CC, et al. Pulp revascularization after root canal decontamination with calcium hydroxide and 2\% chlorhexidine gel. J Endod. 2013;39(3):417-20. doi: 10.1016/j.joen.2012.10.005
55. Shimizu E, Jong G, Partridge N, Rosenberg PA, Lin LM. Histologic observation of a human immature permanent tooth with irreversible pulpitis after revascularization/regeneration procedure. J Endod. 2012;38(9):1293-7. doi: 10.1016/j. joen.2012.06.017

56. Lenzi R, Trope M. Revitalization Procedures in Two Traumatized Incisors with Different Biological Outcomes. J Endod. 2012;38(3):411-4. doi: 10.1016/j.joen.2011.12.003

57. Chen MY, Chen KL, Chen CA, Tayebaty F, Rosenberg PA, Lin LM. Responses of immature permanent teeth with infected necrotic pulp tissue and apical periodontitis/abscess to revascularization procedures. Int Endod J. 2012;45(2):294-305. doi: 10.1111/j.1365-2591.2011.01978.x

Received on: 27/11/2012

Final version resubmitted on: 21/4/2013

Approved on: 4/6/2013 
